Černevičiūtè, J., Strazdas, R., Kregždaitė, R., \& Tvaronavičienė, M. (2019).

Cultural and creative industries for sustainable postindustrial regional

development: The case of Lithuania. Journal of International Studies, 12(2), 285-298.

doi:10.14254/2071-8330.2019/12-2/18

\title{
Cultural and creative industries for sustainable postindustrial regional development: The case of Lithuania
}

\author{
Jūrate Černevičiūtè \\ Faculty of Creative Industries, \\ Vilnius Gediminas Technical University, \\ Lithuania \\ jurate.cerneviciute@vgtu.lt
}

\section{Rolandas Strazdas}

Faculty of Creative Industries,

Vilnius Gediminas Technical University,

Lithuania

rolandas.strazdas@vgtu.lt

\author{
Rusnè Kregždaitė \\ Faculty of Creative Industries, \\ Vilnius Gediminas Technical University, \\ Lithuania \\ rusne.kregždaite@vgtu.lt
}

\author{
Manuela Tvaronavičienè \\ Faculty of Business Management, \\ Vilnius Gediminas Technical University, \\ Lithuania \\ manuela.tvaronaviciene@vgtu.lt
}

Abstract. Under the conditions of globalisation and rapid urbanisation small economies are facing the problem of sustainable regional development, especially in the regions with low population density. Historically, in order to overcome economic disparities in disadvantaged regions, national governments have been taking various strategies for the existing low-tech and cheap-labourbased industry stimulation. However, within open economies and human resource mobility these measures prove to be not sustainable in the long run unless they offer significant benefits associated with life quality. The rise of cultural and creative industries might offer such a complex solution in terms of occupations, cultural development, and variety of activities in the regions. Based on this, we aim to address the question: what factors are important for stimulation of sustainable regional development via cultural and creative

Received: October, 2018 1st Revision: December, 2018

Accepted:

May, 2019

DOI:

$10.14254 / 2071$ 8330.2019/12-2/18 
industries (CCI) in order to reduce their economic, cultural, social, territorial disparities. Factors influencing the development of CCI in the region are identified, and the model for stimulation of regional CCI development by local/regional governments is proposed. This model enables sustainable regional CCI development through stimulation of regional CCI supply and demand in a balanced way.

Keywords: cultural and creative industries, regional development, regional policy, Lithuania.

JEL Classification: D21, O31, O10, O32

\section{INTRODUCTION}

Two main groups of strategies could be identified for local and regional development. In this article we can name them "old" and "new" strategies. "Old" group of strategies for the development of regions can be described as "industrial revitalization". Such strategies focus on stimulation of industrial companies' development. According to this strategy, rural regions including small cities are competing with major cities for attracting investments in high-tech or even low-tech industrial companies. Regions are often losing in this competition because modern production requires skilled workers and developed transport infrastructure, which, unfortunately, are often not available in smaller cities and rural regions. This approach merely represents the initial stage of regional development strategies that were seen as a some sort of replication of national strategies.

"New" strategies for regional development are aiming at developing regional innovation systems, integrating traditional, context-linked, regional knowledge and codified, world-wide available knowledge in order to stimulate regional endogenous potentials (Bezpalov et al., 2019; Pogodina et al., 2019; Zeibote et al., 2019; Petrenko et al., 2019). Some of the "new" strategies are not linked to science and technology advantages, and are rather of "traditional" occupational domain, using local resources, such as culture, tourism, recreation, and particular endogenous knowledge and skills. Regional development based on stimulation of regional cultural and creative industries (CCI) is one of such "new" strategies. Thus, the role of cultural and creative industries (CCI) here is essential, as it offers a platform for accumulation of these potentials, and packaging them into socioeconomically meaningful products, mainly constructed around tourism and service (EU Commission, 2010b; Cooke \& De Propris, 2011). The use of the terms "creative and cultural industries" can vary significantly from one context to another. In this paper, we adopt a rather broad approach based on the following definition presented in European Commission's document „Green Paper: unlocking the potential of cultural and creative industries“. „Creative and cultural industries are those industries which use culture as an input and have a cultural dimension, although their outputs are mainly functional“ (EU Commission, 2010b). Besides the traditional arts sectors (performing arts, visual arts, cultural heritage), CCI also include film, DVD and video, television and radio, video games, new media, music, books and press. It also include architecture and design, tourism and the new technologies sector.

It is important to emphasise that in a long term, sustainability of regional CCI development strategy could be ensured only by active participation of local communities, but in many cases these communities lack skills and the ability to identify local CCI assets, to develop and implement regional CCI strategy (Clifton et al., 2015). In this respect neo-endogenous approach could be vital to ensure sustainability and efficiency of regional CCI development strategy (Bosworth et al., 2016). Targeted promotion of CCI 
development creates a unique regional CCI identity (brand) that is becoming a competitive advantage for regional CCI and associated businesses (Cloke, 2007; UNESCO, 2015; CCS, 2015; Yang \& Černevičiūtè, 2017). In this way, CCI business in a region can successfully expand, create new jobs and contribute to regional prosperity. The CCI promotion strategy is in no way in contradiction with the 'industrial recovery strategy'. These strategies can even complement each other. Thus, a well-developed regional CCI can turn it into a more attractive industrial resource for expanding production (CCS, 2015). Still, CCI in many cases remain outside of regional innovation strategies. However, matching the demand and supply factors for CCI development at the regional level, especially as we address small peripheral subregions, is a challenging task (Petraite, 2009). Development of CCIs in a fragmented manner by local and regional government leads to underexploitation of the existing creative potential of the local and regional, cultural and geographical communities. Given the embeddedness of the peripheral CCI in local cultures and knowledge, community involvement is essential for the success of CCI as a tool for sustainable development. Based on this problem formulation, we aim to identify supply and demand factors influencing the development of regional CCI. Stimulation of these factors enables local/regional governments to develop sustainable regional CCI strategy.

The research method applied is a case study, with one selected country - Lithuania. Lithuania was chosen because of the current negative trends in its regional development. The economic-cultural potential is concentrated in the major cities of Lithuania, so a large part of inhabitants in the regions, especially young people, emigrate to larger cities or abroad. Loss of population in rural regions with small cities leads to increased disparities between Lithuanian regions. The regions with major cities are growing in terms of population and economic development. At the same time, rural regions with small cities are getting less populated while youth unemployment in these areas is only growing (Rimkuviene \& Sakalauskaite, 2018). Development of Lithuanian regions is becoming a major challenge for regional and central authorities. An important question arises: how to stimulate sustainable development of Lithuanian regions in order to reduce their economic, cultural, social, territorial disparities? Social, economic and territorial cohesion is a key objective of the EU and have to be pursued by all the Member States (EU Commission, 2010a). Efforts have been taken to coordinate regional policy development in Lithuania at the national level. The White Paper (NRPT, 2017) states that the pillar of regional policy in Lithuania inclusive, empowering and competent regions, and the effectiveness of regional policy depends on the effectiveness of cooperation - promoting the specificity of Lithuanian regions, revealing their strengths, shaping the identity of each region through creative localities . This document indirectly promotes "old" regional strategy development for postindustrial regions as in post-industrial regions CCI is usually not well developed. Other important document which outlines the most important strategic directions for Lithuanian economy and society development and could serve as guidelines for developing CCI strategies in Lithuanian regions is "Directions of Culture and Creative Industries Policy Development 2015-2020" approved by the Government of the Republic of Lithuania (LRKM, 2015). This document is a very good initiative of Lithuanian Government aimed to stimulate CCI development at national level, however, it has almost no effect on regional CCI strategies development in Lithuania.

Within Lithuania, the Alytus region was chosen, as a characteristic disadvantaged region of postindustrial development, with its negative population growth and economic decline trends. The case study was carried out by means of the triangulation method, where regional statistics analysis, qualitative interviews with core stakeholders, and observation of cultural and creative objects and industries were combined in order to extract critical factors influencing CCI development within a region, and identification of their influence on sustainable regional development.

The paper is structured as follows. First, we discuss the theoretical perspectives from the analysis of the role of local communities in regional development, with the specific focus on CCI engagement. 
Second, we look at CCI implications for regional development policy, and contemporary approaches to it. Third, we present the application of the asset-based community development approach for CCI development in regions, which is later used for empirical analysis.

In the fourth part of the paper, we present the case analysis methodology, which embraces regional development analysis in terms of CCI as based on regional statistical indicators and stakeholder interviews that allowed revealing underpinnings of the community engagement, CCI development, and also addressing regional development challenges.

Finally, we conclude with the CCI development model based on supply and demand of CCI within communities that is aimed at socioeconomic development of the peripheral regions.

\section{LITERATURE REVIEW}

Currently there are three dominant approaches used to stimulate regional development —exogenous, endogenous and neo-endogenous. These approaches can be distinguished according to the different roles of the stakeholder groups: drivers, who identify regional development strategy; implementers, who carry out the local development action; and, enablers, who facilitate action implementation (Ray, 2006). Exogenous development is a top-down approach that is driven, implemented, and enabled by external stakeholders. Endogenous approach is focus on regional development actions, which are driven, implemented, and enabled by internal stakeholders. Neo-endogenous approach depends on 'bottom-up' activities that integrate external influences to increase local knowledge, local resources and empowering local people to be central to development processes (Bosworth, 2015; Ray, 2006; Bosworth et al., 2016). The efficiency of neo-endogenous approach is proven by many scholars and practitioners. As a good example are the results of LEADER programme initiated by European Union to support rural development projects in order to revitalise rural areas and create jobs (Bosworth et al., 2016).

Regional CCI development theories focus on the endogenous "grassroots creativity" mainly, i.e. key role of local and regional communities to achieve certain regional development goals (Cloke, 2007; Borrup, 2006; Eversole, 2005; McGranahan \& Wojan, 2007). Many examples of these include the activities of rural and local communities in Australia, Latin America and EU (KATARSIS, 2010; White, 2010), which reveal different examples of cultural, identity and creative expression, attracting market resources to specific communities and regions. Exogenous regional CCI development strategies can be successful at some point, they can underestimate the deeper role of creativity: helping communities to reflect on their own experiences, to define and pursue their own regional development goals, rather than setting other goals for the community.

An important role in activating the creativity of local communities for the purposes of local development is assigned to the "extra-local" forces, i.e. experts in CCI development (Ray, 1998). They can empower local communities to embrace local culture and arts, stimulate systematic, entrepreneurial approach for regional CCI development. This could be called neo-endogenous approach for regional CCI development. Arts and culture activation could be achieved in several ways (Eversole, 2005), i.e. first, when arts and creative activities become means of creating social cohesion (community-building and development activities); second, when arts and creative activities become means of promoting and communicating towns and regions (an indirect economic activity strategy; third, when arts and creative activities become a precondition for economic success and an engine of development.

Regions are geographical locations with physical and cultural characteristics, and also geographical areas with unique features of common identity. Particular attention is paid to economically unsuccessful regions where the development of the region is linked to the livelihood and way of life of its population. Increasingly, regional development is perceived as decentralized, based on self-help approach (Green \& 
Haines, 2015; Florida, 2008; Sacco et al., 2009). Local communities are encouraged to become more "innovative", "entrepreneurial" and "creative", developing solutions to their economic, social or environmental challenges. The communities of lagging regions can work together to attract external resources in all possible areas - tourism, try to sell local products such as crafts or food and etc.. In order to attract the resources to the region, communities must find something unique or create such uniqueness (CSES, 2010; KEA, 2009).

The "extra-local" approach often leads to the use of local culture, identity, creativity and the enthusiasm for the practical goals of regional development. Communities thus use the "raw material" of art - not necessarily professional art, but folk art festivals, traditional fabrics, local stories, and so on. The theory of regional development supports the view that the use of local creative potential should stand at the core of regional development strategy.

Research in creative industries and creative regions draws attention to the fact that art in particular and creativity in general are important for regional development (Petridou \& Ioannides, 2012; Kačerauskas, 2016). In case of success, such sub-systems of creative industries as film production, music, visual arts, etc. have a direct economic impact on the region. The impact of creative industries on the economy and society is at the heart of the European Union's political agenda - 2012. The European Commission has set out a political agenda for the dissemination of the arts, culture and creative industries (EU Commission, 2012).

Art is becoming important in promoting creativity in general, as well as in supporting regional development strategies. The arts do not offer concrete solutions, but help to enlighten the way, inspire people and communities. Artistic creativity is much more important than other forms of creativity in the context of community creativity and social innovation, because it has a unique ability to challenge customs and social structures and redesign collective memory and identities. The metaphorical nature of art allows transcending boundaries, what seems obvious and facilitates the communication of deep values and feelings. Public art is ideal for individual and collective self-promotion, for reconstructing local and social identities, and for strengthening the sense of belonging. In the context of poverty, art plays the role of a facilitator of critical thinking and communication (Campbell \& Martin, 2006), stimulating the creativity of community members and helping to create new responses to unresolved political, social, economic and environmental problems.

Supporting artistic activities can become a tool to combat or reverse the reproduction of inequality and helplessness by creating incentives for social innovation, enhancing personal and collective confidence (André \& Abreu, 2009). Artistic creation is increasingly recognized as an important component in creating creative environments - based on the assumption that artistic creativity inspires and encourages creativity in other areas of human activity. Rural tourism (nature, adventures, local material and intangible culture) are possible ways to overcome obstacles. European Union support for rural development focuses on social, as well as environmental and landscape conservation and economic diversification issues - support for rural tourism, bio-agriculture, heritage and cultural initiatives (Borrup, 2006).

The most important (decisive) preconditions for the community's creativity to flourish are diversity, tolerance, collective learning and critical thinking (Borrup, 2006). Diversity is important because creative solutions are based on the combination of different experiences, ideas and perspectives. This can be due to the mobility of different cultural groups, which work and share the same space, or because of the interaction between different social groups. Collective learning and critical thinking stimulate innovation.

Creating a creative and innovative environment for local communities in the regions depends to a large extent on the ability to overcome existing divisions between stakeholders and reconstruct social relationships. Leadership is the solution to the problem - relationships with the community are usually created through emotional relationships (Green \& Haines, 2015; Stasiulis, 2017). It contributes to trust 
that fosters a sense of community; turn small details into identity references common to the whole community; encourages feelings and emotions.

In the 1970s most community development practitioners started with the communities' weaknesses, needs, problems or shortcomings that need to address. It has been noticed that the problem-based approach presents a "mental map" of politicians, practitioners and professionals communicating with communities that did not allow them to see the potential of the communities themselves (Cameron \& Gibson, 2005). A problem-based approach describes people and their circumstances in things that they lack (resources) or inadequacies: e.g. poor skills, poor understanding, and limited knowledge. This orientation told people that they were incompetent, incapable, ignorant, and incapable. Later, a model was created that offered a different - asset-based community development (ABCD) approach, reflecting the strengths of the community, which originated in social work theories and practices (Saleeby, 1996). ABCD access originated from the criticism of problem-based community development policies and practices (Kretmann \& McKnight, 1993).

The asset-based community development approach (ABCD) is based on two principles: First, all communities (people and organizations) manage assets, abilities, competencies and networks; second, effective community development begins with identifying these assets, building relationships with and within the community, and using resources and relationships to deliver the visions and plans that are emerging in the process. The focus is on competencies and opportunities, not on weaknesses. From an $A B C D$ point of view marginalized communities are not enough to finance; in order to achieve higher development, it is necessary to empower them - they cannot be treated as powerless or dependent on government. The essence of any community resource, where people's skills and qualities are identified and supported, is their formal and informal associations, networks and relationships. The first of all are the assets and networks of knowledge that cannot be identified if communities focus on the weaknesses and problems. This specifically refers to "social assets and social capital inherent in the relationships underlying local associations and informal networks" (Mathie \& Cunningham, 2003).

\section{METHODOLOGY}

The elements of $\mathrm{ABCD}$ model was used for the construction of the interview questions for identification factors influencing the development of CCI in Alytus region. The ABCD model was chosen due to the fact that post-industrial regions such as Alytus region have limited identified assets (people, organizations, resources, abilities, competencies, networks, CCI objects), which are very relevant for CCI development in post-industrial regions. The ABCD model focus on the identification of these assets. Empirical research was executed in two stages. Quantitative as well as qualitative research methods were used to determine the factors of a regional CCI development.

The Alytus region has been chosen because of its typical characteristics as a post - industrial region of Lithuania, where no targeted CCI development was implemented. The first stage of the research was implemented in 2015 - 2016, with the focus on the macro-economic conditions of CCI in Alytus region. The aim of the quantitative research was to identify status, trends of CCI development in Alytus region. This stage is very relevant for understanding and analysis of qualitative research data.

Alytus region consists of Alytus city and Alytus district municipalities. It situated in Southern part of Lithuania. The development of cultural and creative industries was analyzed by selecting 35 branches according to the NACE (Rev 2.0) classification.

The criteria of analysis were as follows: changes in number of CCI companies, turnover, number of employees, and the dynamics of the most important CCI branches. In the second stage of the research (in 2016), interviews with representatives of 11 cultural and creative industries, tourism, communities and the 
municipality of Alytus region were carried out. Respondents were selected so that the local situation could be reviewed from the perspective of strategy makers (municipality) and implementers (community, cultural institution, tourism center, business). Some of the respondents play several roles. As an example position of Chairman of local community is usually not paid/volunteering position. The semi-structured interview method was applied aiming at identifying factors relevant for regional CCI development.. The interviews were open-ended, allowing the stakeholders to reflect on their experiences about CCI development, the challenges they encountered when developing a CCI within communities, and evaluations of outcomes. The interview questions also dwelt upon the arising challenges and their solution means. The informants had a relatively broad freedom to expand on their point of view as well as to describe personal expertise and attitudes. Each interview lasted between one and three hours.

The interviews have been recorded, and later the latent content analysis was performed. Recorded texts were transcribed and coded. Coding was done in two stages. At the first stage of the coding, relevant factors for regional CCI development in the transcribed text were identified and highlighted. Then identified factors were grouped into two categories - supply and demand factors for regional CCI development. $\mathrm{ABCD}$ model was used mainly for identification topic of the semi-structured interviews.

\section{EMPIRICAL RESULTS AND DISCUSSION}

\section{Cultural and creative industries in Alytus region: socio - economic development perspective}

From 2001 to 2017, the population of Alytus city has decreased by 18668 thousands inhabitants, or by $26.12 \%$. The largest decrease in population was in 2011 (3328 inhabitants). In 2017, 55792 persons lived in Alytus city (see Figure 1).

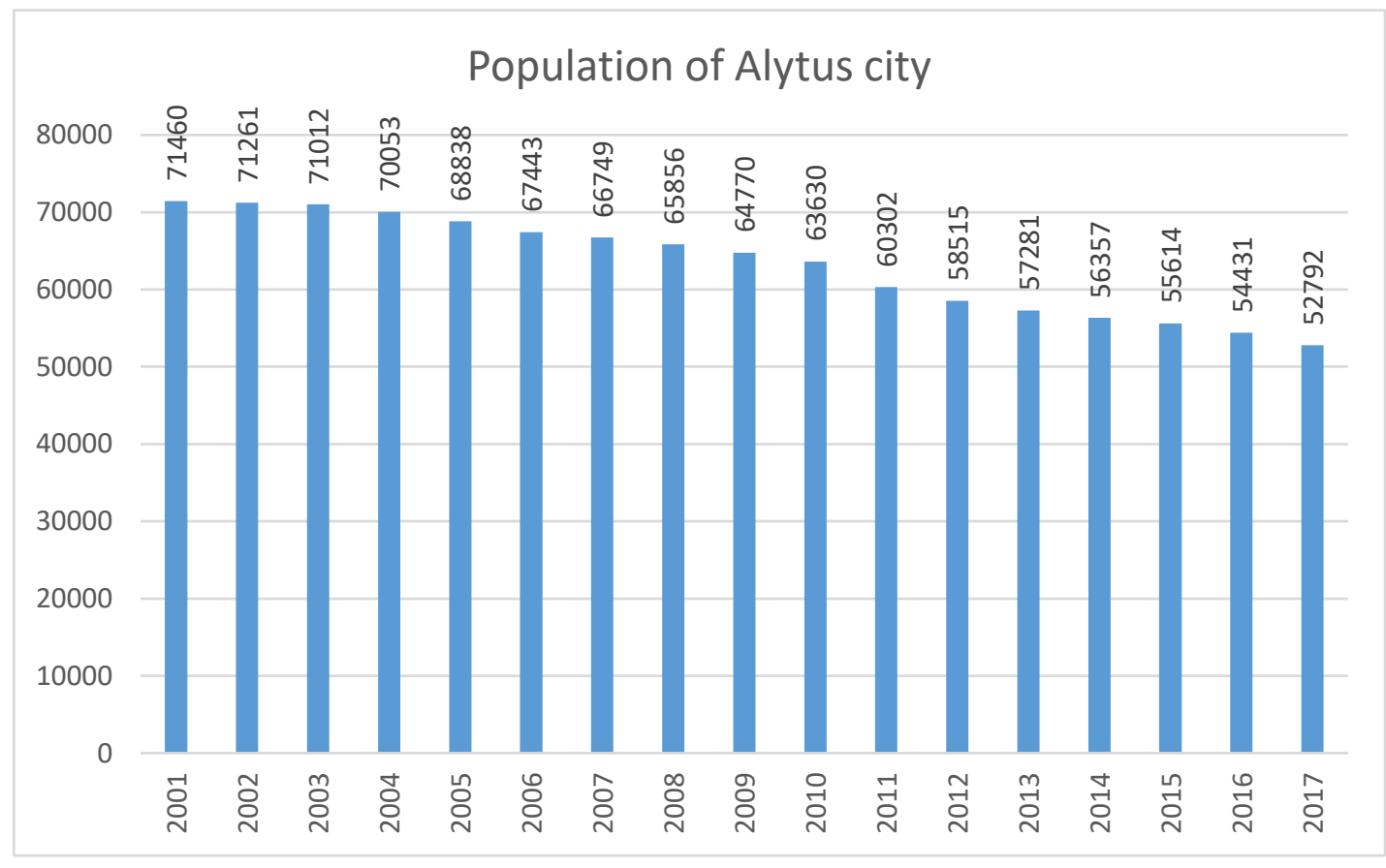

Figure 1. Population of Alytus city (2001-2017)

Source: Lithuanian Department of Statistics 
While analyzing the composition of the population in 2017 of Alytus region, there is a fairly even distribution among the age groups, but the declining birth rate is visible (up to $9.2 \%$ of the total population up to 9 years old) and population aging: $40.7 \%$; the total population is over 40 years old. The aging of the population is also visible in the analysis of the dynamics of population composition by age in the period from 2006 to 2017.

This population dynamics is highly influenced by internal and international emigration. From 2013 the number of people emigrated is growing every year. In 20162400 people left Alytus region. More than $40 \%$ is international emigration. Alytus region overall (net) migration over period 2012-2016 was negative. The net migration of Alytus city is about 3 percent from the total population per year. The emigration is an important factor causing decrease of population in Alytus region.

Over the last five years, unemployment rate (the ratio of the registered unemployed to the working age population) in Alytus region decreased from $14.8 \%$ in 2012 to $11.3 \%$ in 2016, however, it was significantly higher than average rate in Lithuania (8.1\%).

Alytus region tourism has been evaluated while using two indicators: the number of visitors of Alytus Tourist Information Center and the number of visitors in tourist accommodation establishments of Alytus region. Approximately 10,000 visitors visit Alytus Tourism Information Center every year, about 25 percent of visitors are from abroad. Most of foreign tourists come from Poland (42\% in 2016), Latvia (13\% in 2016), Belarus ( $9 \%$ in 2016), Germany ( $9 \%$ in 2016). Most foreign tourists are passing by visitors.

Similar trends in arrivals to Alytus region are also seen in the data of Alytus accommodation establishments. In Alytus city, the number of accommodated tourists for the period 2012-2014 increased by $46.4 \%$ from 6189 to 9061 tourists, but from 2014-2016 the number of tourists dropped by20.6 \%) to 7192 tourists. The number of accommodated tourists in Alytus district for the period 2012-2016 increased by $68.9 \%$ from 1554 to 2626 tourists.

According data of Alytus Tourism Information, in 2016 over 60,000 persons used services provided by CCI companies in Alytus region. Almost 24 thousand persons visited Alytus city museums and other cultural sites. In 2016 sports there were tourists about 8 thousand, they spent 2-4 days in Alytus region.

The number visitors of amusement parks, museums and educational programs in Alytus region since 2012 this number has doubled in 2016. Most visitors are attracted by entertainment (65\%), educational programs and craft centers $(23 \%)$. museums and exposition (12\%).

According Lithuanian Department of Statistics, 2181 enterprises were registered in Alytus city and Alytus district in 2016, which totally employed 17649 employees. There were 320 (14.7\% of total enterprises), which can be attributed to the cultural and creative industries (see Figure 2). These enterprises generated 55.9 million euros turnover (4.2\% of total turnover). In comparison the manufacturing sector in 2016 generated 497.8 million euros (37.6 \% of total turnover), the wholesale and retail trade -454 million euros $(34.3 \%$ of total turnover, the agriculture, forestry and fishing -16.4 million euros (1.2\% of total turnover). CCI sector in Alytus city and Alytus district has demonstrated even higher growth than manufacturing sector. For the period 2010-2016 the turnover of CCI enterprises increase by $58 \%$ (see Fig. 3). The turnover of manufacturing companies for the same period increase by $55 \%$. 


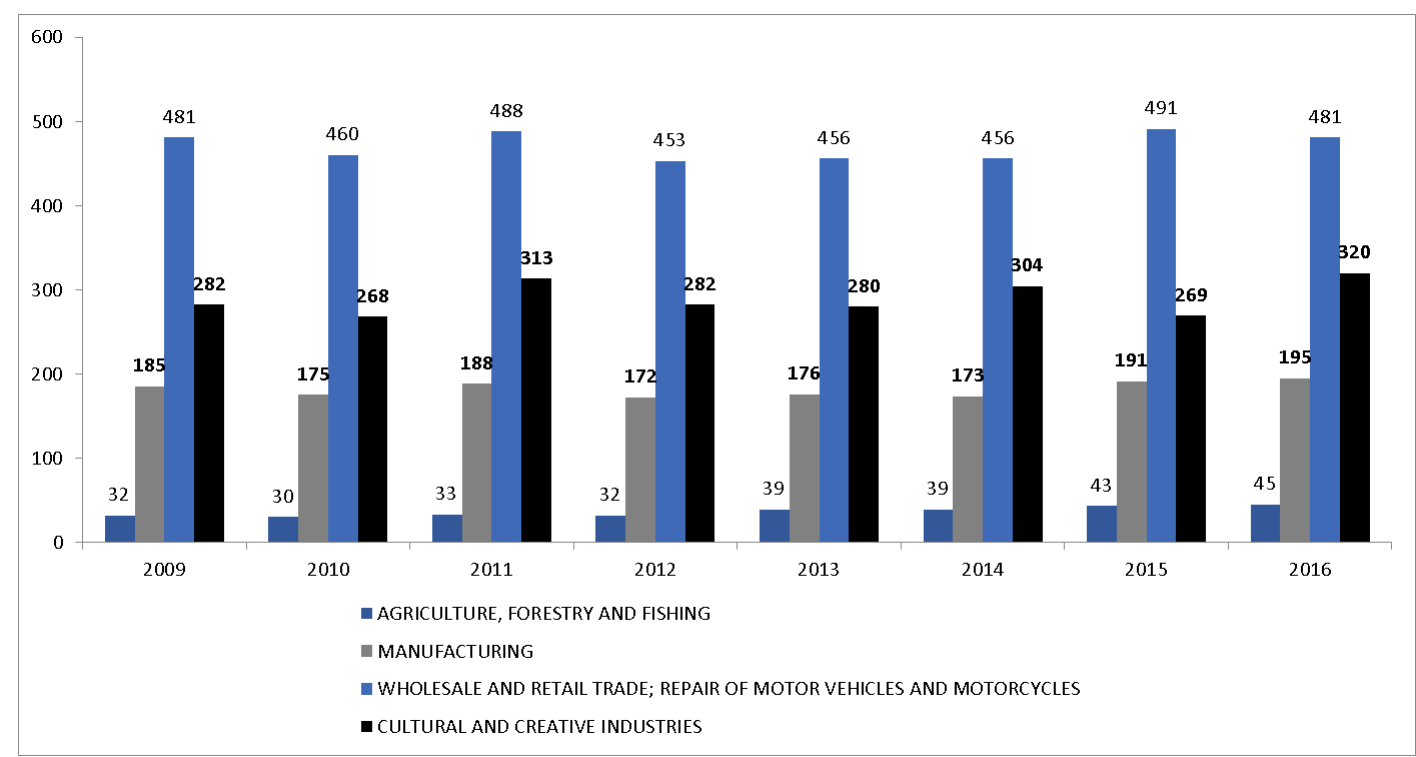

Figure 2. Dynamics of number of enterprises registered in Alytus city and district municipalities (2009-2016)

Source: Lithuanian Department of Statistics

In 2014 here were. Most of the CCI companies are engaged in stage construction activities (57 companies, or $18,7 \%$ of all CCI companies), advertising agencies (47 companies or $15,4 \%$ of all CCI companies), engineering activities (43 companies or 14,1\% of all enterprises), artistic creation (36 companies or $11.8 \%$ of all companies).Most employees of CCI sector are employed in advertising agencies (86 employees, or 18\% of all Alytus CCI companies), engineering companies (63 employees, or 13\% of those working in Alytus CCI sector), stone cutting and cutting operations (40 employees, or $8 \%$ of those working in Alytus CCI sector) stage-building activities (27 employees or 5\% of those working in Alytus CCI sector).

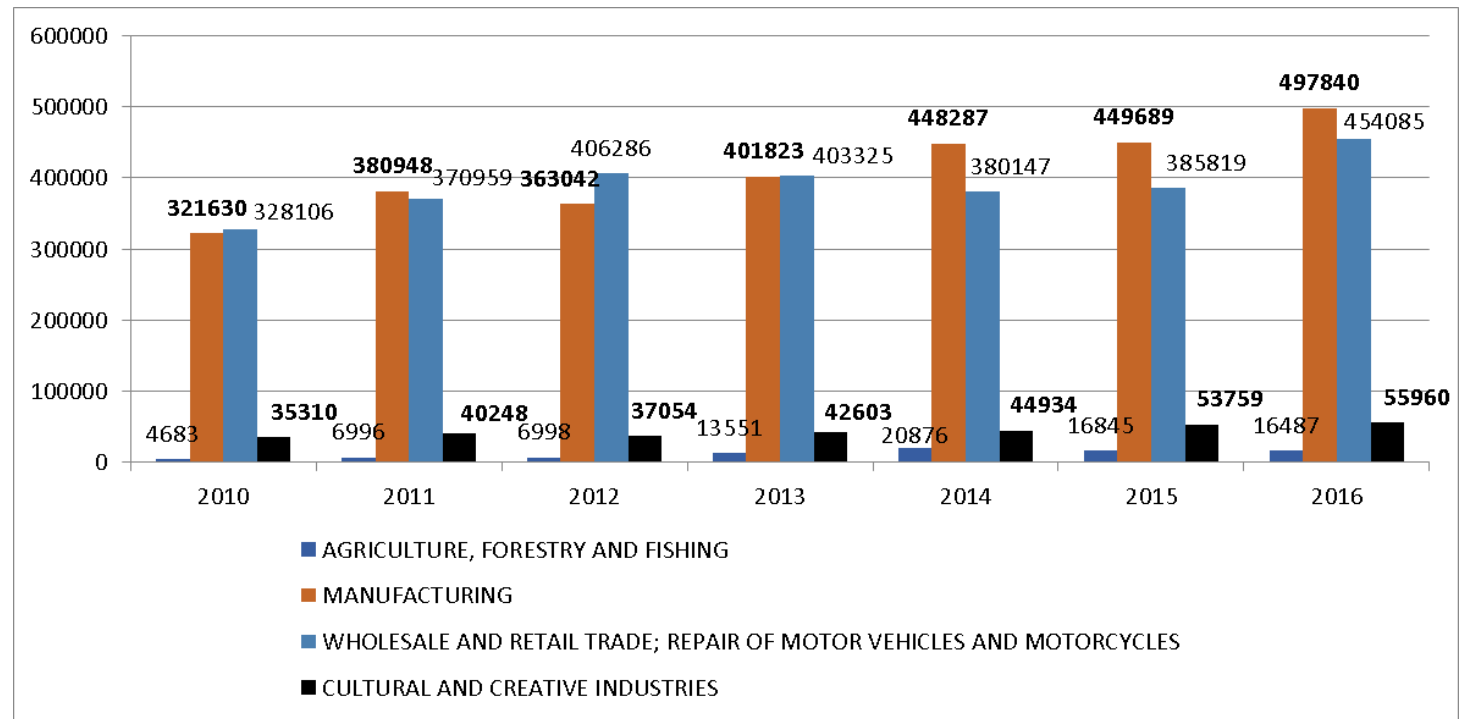

Figure 3. Dynamics of turnover (in thousands euros) of the enterprises registered in Alytus city and district municipalities (2009-2016)

Source: Lithuanian Department of Statistics 
Based on the analysis of CCI development of trends, we approach a positive demand driven trend for CCI development that is mainly driven by domestic and foreign tourism consumption. However, for the understanding of community role, benefits and participation of demand and supply factors creation, qualitative research was executed, as based on ABCD model.

\section{Regional CCI development model based on supply and demand factors}

The identification of factors for the regional CCI development was based on the interviews with representatives of cultural and creative industries, tourism sector, communities and the municipality of Alytus region. In total, 11 interviews were conducted. The analysis of interviews have revealed critical factors, challenges and enablers for CCI development, and its underpinnings with regional development goals. The content analysis, following the asset - based model for community development, is grouped along the supply and demand factors, while revealing a specific focus on regional and community development challenges, as presented below.

Our study demonstrated that post - industrial peripheral regions, such as Alytus region is, demonstrate good potential to stimulate regional CCI in order to achieve sustainable development of the region. The Asset -Based Community Development (ABCD) method (Kretmann \& McKnight, 1993) can be successfully applied for regional CCI development. Nevertheless, ABCD method has its limitations as this method mainly focuses on the identification and stimulation of regional assets and resources i.e. regional CCI's supply factors. Our study of CCI sector development in Alytus region demonstrated that demand factors play a crucial role in regional CCI development, following the general model of competitiveness of regions. As an example, the drop in consumption during the economic crisis in 20082009 has significantly reduced the demand of CCI products and services in Alytus region resulting in significant drop of turnover, value added and caused bankruptcy of number of CCI companies (see Figure 3).

We were able to identify and group the factors for sustainable regional CCI development into supply and demand related factors. The following regional CCI supply factors were identified: Number of regional CCI objects; products and services; Attractiveness of CCI objects (local, national, international); Synergy of CCI objects and events; the involvement of local communities in the development of CCI activities; Initiative of the regional government in the development of CCI; funding for CCI development. The following regional CCI demand factors were identified: Awareness and visibility of regional CCI objects, products and services in cyberspace; Existing and potential users of regional CCI products and services (local residents, Lithuanian and foreign residents); Entrepreneurship and ability of regional suppliers of CCI products and services to adapt to changing user needs; Applying measures to promote regional CCI products and services; Integration of regional CCI objects into national and international networks. It is important to emphasize that some of the factors such as "Existing and potential use of regional CCI products and services" are not directly depend on the activities of the local and regional authorities nor communities. Macro-economic events and actions such as economic crises, national strategies and regulations could have a big impact on the regional CCI development.

The "Regional CCI development model based on supply and demand factors" was developed (see Fig. 4). This model allows sustainable regional CCI development by stimulation regional CCI supply and demand in a balanced way. The growing regional CCI supply attracts more CCI users. At the same time more CCI users allow more resources to be generated for the further development of regional CCI services and products. Such kind of stimulation allows to achieve and to maintain balance between the regional CCI supply and demand. Before stimulation actions to be implement, local and regional authorities have to evaluate balance between regional CCI supply and demand. If supply is the weakest 
side of regional CCI, more actions are to be focused on regional CCI supply stimulation. In this case more efforts need to be taken to develop regional CCI objects, products and services, increase their CCI attractiveness not only for local but also for national and international customers

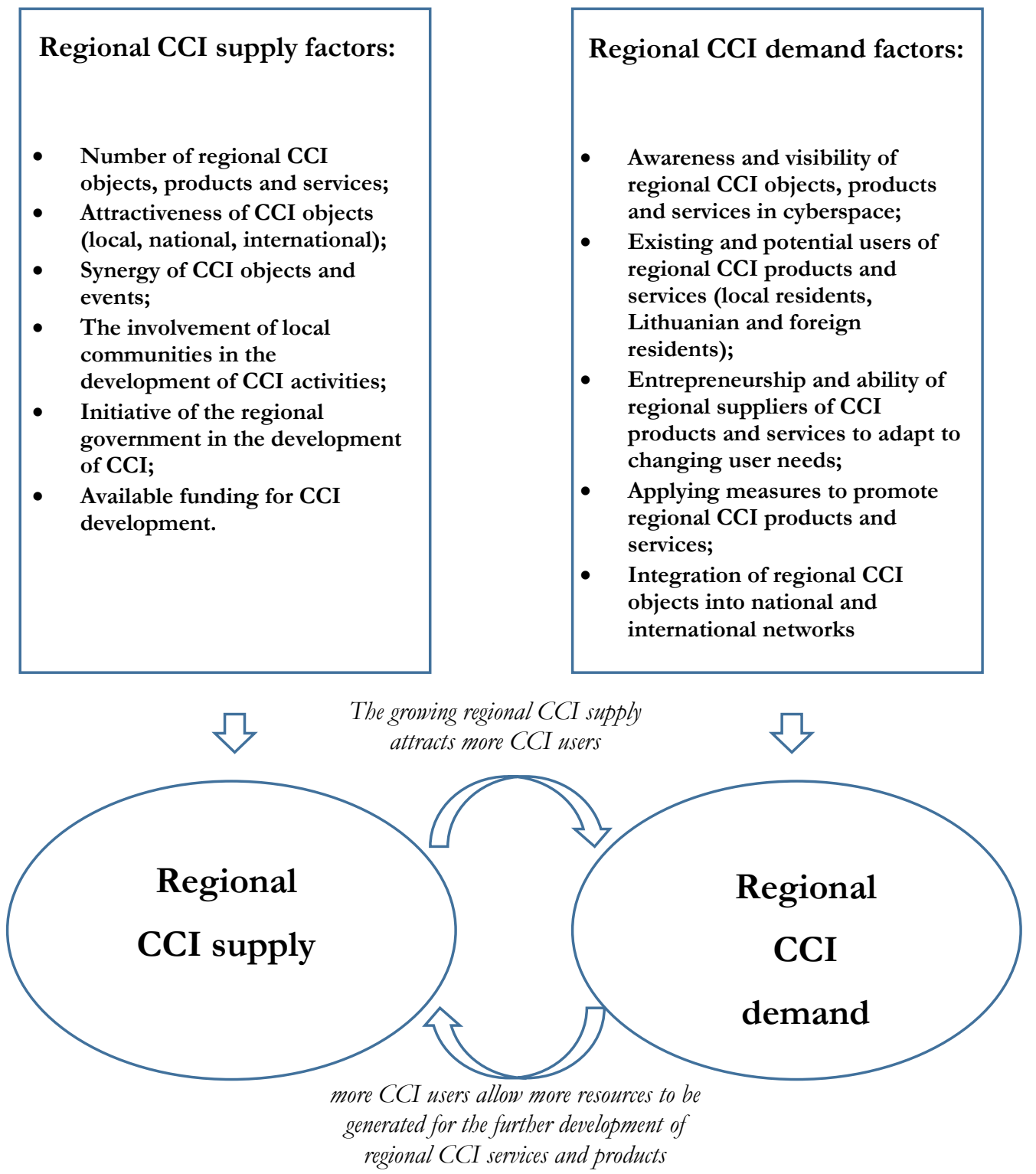

Figure 4. Regional CCI development model based on supply and demand factors

(Supply - Demand model)

For the identification of regional CCI object, product and services the Asset and Based Community Development (ASBCD) model could be used. 


\section{CONCLUSION}

Our study demonstrates that the development of post - industrial regions is a challenging task due its negative demographic and socio-economic development trends. CCI development perspective allows embedding the bottom- up approach in the actual regional development strategies with positive impacts. The study of community involvement while applying ABCD perspective, has demonstrated, that communities with the right policy support measures initiated by local and regional government, are able to mobilize around cultural and creative industries, and reinvent the development trends towards positive trajectories. New recreational, tourism, and cultural services are being formed around the CCI developments, which produce positive effects on employment and social cohesion. Last but not least, the social development of CCI cannot be undermined, as it serves as a tool for community integration and reintegration (in case of returning migrants). Factors influencing the development of CCI in the region are identified, and the model for stimulation regional CCI development for local/regional governments is proposed. The proposed supply - demand model for regional CCI development, addresses the need of local communities, and also integrates economic potentials for development, and offers a dynamic approach to CCI development, as an opposite to supply driven ABCD model. In this way, CCI development is approached from the regional competitiveness perspective, and is able to offer a balanced view for community embeddedness in regional sustainable development goals and actions.

The model proposes a constant monitoring and balancing between the supply and demand factors, and identification of asymmetries and "bottlenecks" at the first stage while applying regional statistical analysis and qualitative investigations by local/regional governments. Application of ABCD method allows identification of endogenous CCI assets, and establishes the base for creative product development and increase of supply for touristic attractions. However, ABCD method has limitations when the asymmetry is on the demand side, and thus demand driven CCI policy measures shall be implemented, while focusing on the demand increase, tourism advertisement, and etc.. The method we propose allows focusing on the immediate regional development needs, and designing precise policy interventions on the supply either demand side.

The limitation of our study is based on the single case choice. More regions could be studied in order to estimate specificities of the regions especially the specificities of historically touristic regions and national capital regions. The future research shall focus on other peripheral post-industrial regions and possibly apply longitudinal approach.

\section{REFERENCES}

André, I., \& Abreu, A. (2009). Social creativity and Post-Rural Places: The Case of Montemor-o-Novo, Portugal. Canadian Journal of Regional Science. Revue Canadienne des sciences regionals, 32(1), 101-114. https://www.researchgate.net/publication/251515516 Social creativity and postrural places the case of Montemor-O-No vo Portugal

Bezpalov, V.V., Fedyunin, D.V., Solopova, N.A., Avtonomova, S.A., \& Lochan, S.A. (2019). A model for managing the innovation-driven development of a regional industrial complex. Entrepreneurship and Sustainability Issues, 6(4), 1884-1896. http://doi.org/10.9770/jesi.2019.6.4(24)

Borrup, T. (2006). The Creative Community Builder's Handbook: How to Transform Communities Using local Assets, Arts and Culture. Saint Paul: MN Fieldstone Alliance; Markusen.

Bosworth, G. (2015). Community-Based Entrepreneurship and Rural Development. International Journal of Entrepreneurial Behavior \& Research, 21(3), 501-503. https://doi.org/10.1108/IJEBR-10-2014-0189 
Bosworth, G., Annibal, I., Carroll, T., Price, L., Sellick, J., \& Shepherd, J. (2016). Empowering Local Action through Neo-Endogenous Development, the Case of LEADER in England. Sociologia Ruralis, 56(3), 427-449. https://doi.org/10.1111/soru.12089

Cameron, J., \& Gibson, K. (2005). Building community economies: A pathway to alternative 'economic' development in marginalised areas. In P. Smith, T. Reddel, A. Jones (Eds.) Community and Local Governance in Australia. Kensington: UNSW Press. P.172-191. https://www.booktopia.com.au/community-and-localgovernance-in-australia-paul-smyth/prod9780868407753.html

Campbell, M.S., Martin, R. (Eds.).(2006). Artistic Citizenship: A Public Voice for the Arts. N.Y.: Routledge. https://doi.org/10.4324/9780203960448

CCS 2015 Cultural and creative spillovers in Europe: Report on a preliminary evidence review. T. Fleming Creative Consultancy, 2015.

P.15. https://www.artscouncil.org.uk/sites/default/files/Cultural creative spillovers in Europe full report.pdf

Clifton, N., Comunian, R., \& Chapain, C. (2015). Creative Regions in Europe: Challenges and Opportunities for Policy. European Planning Studies, 23(12), 2331-2335. http://doi.org/10.1080/09654313.2015.1104815

Cloke, P. (2007). Creativity and tourism in rural environments. In G. Richards and J. Wilson (eds.) Tourism, Creativity and Development (pp. 37-47). Oxon, UK: Routledge. http://doi.org/10.4324/9780203933695

Cooke, Ph., \& De Propris, L. (2011). A policy agenda for EU smart growth: the role of creative and cultural industries. Policy Studies, 32(4), 365-375. http:// doi.org/10.1080/01442872.2011.571852

CSES. (2010). Study on the Contribution of Culture to Local and Regional Development - Evidence from the Structural Funds, Centre for Strategy and Evaluation Services http://www.europa-foerdertkultur.info/fileadmin/7 Europa foerdert Kultur/EfK Regionale Entwicklung/Report Contribution of C ulture to Local and Regional Development.pdf

EU Commission. (2012). Promoting cultural and creative sectors for growth and jobs in the EU. Brussels: EU Commission, COM https://www.eesc.europa.eu/en/our-work/opinions-information-reports/opinions/communicationpromoting-cultural-and-creative-sectors-growth-and-jobs-eu-com2012537

EU Commission, (2010a). EUROPE 2020: a strategy for smart, sustainable and inclusive growth. Brussels: EU Commission, COM (2010). https://eur-lex.europa.eu/legal-content/en/ALL/?uri=CELEX\%3A52010DC2020

EU Commission, (2010b). Green Paper: unlocking the potential of cultural and creative industries. Brussels: EU Commission, COM (2010) 183. https://eur-lex.europa.eu/legal-content/EN/TXT/?uri=celex\%3A52010DC0183

Eversole, R. (2005). Creative Regions and the Market: Art, Culture and Regional Development. Double Dialogues, 3. https://www.anzrsai.org/assets/Uploads/PublicationChapter/76-8eversolerevised.pdf

Florida, R. (2008). Who's Your City? New York: Basic Books. http://www.creativeclass.com/richard florida/books/whos your city

Green, G.P., \& Haines, A. (2015). Asset Building \&Community Development. SAGE Publications, Inc; Fourth edition https://www.amazon.com/Asset-Building-Community-Development-Green/dp/1483344037

Kačerauskas, T. (2016). Creativity Management: Towards Soft Control. Economics and Sociology, 9(4), $336-343$. doi:10.14254/2071-789X.2016/9-4/21

KATARSIS. (2010). Social Innovation: Collective action. Social Learning and Transdisciplinary Research, http://citeseerx.ist.psu.edu/viewdoc/download?doi=10.1.1.670.9030\&rep=rep1\&type=pdf (last accessed 22 February 2019

KEA. (2009). The impact of culture on creativity. European Commission. http://www.keanet.eu/docs/impactculturecreativityfull.pdf

Kretmann, J. P., \& McKnight, J. L. (1993). Building Communities from the Inside Out: A Path Toward Finding and Mobilising a Community's Assets. - Evanstone, IL: Institute for Policy Research http://www.ekarifoundation.org/wpcontent/uploads/2013/06/Kretzman McKnight BuildingCommunitiesInsideOut.pdf 
LRKM. (2015). "Kultūros ir kūrybinių industrijų politikos 2015-2020 metų plètros krypčiu programa”. Lietuvos Respublikos kultūros ministerijos $2015 \mathrm{~m}$. liepos 31 d. issakymas Nr. IV-524. https://eseimas.lrs.lt/portal/legalAct/lt/TAD/4a028c503a6f11e598499e1e1ba6e454

Mathie, A., \& Cunningham, G. (2003). From clients to citizens: Asset-based Community Development as a strategy for community-driven development. Development in Practice, 13(5), 475-486. https://www.jstor.org/stable/4029934

McGranahan, D. A., \& Wojan, T. R. (2007). Recasting the creative class to examine growth processes in rural and urban counties. Regional Studies, 41(22), 197-216. https://doi.org/10.1080/00343400600928285

NRPT. (2017). Lietuvos regionines politikos Baltoji knyga darniai ir tvariai pletrai 2017-2030. Nacionalinè regioninè plètros taryba,

2017.

https://vrm.lrv.lt/uploads/vrm/documents/files/LT versija/Naujienos/Regionines politikos baltoji knyga 20171215.pdf

Petraite, M. (2009). Fostering Innovation: Matching Innovation Support Services Supply and Demand at Regional Level. Social Sciences, 65(3), 7-17. Retrieved from http://search.ebscohost.com/login.aspx?direct=true\&db=sih\&AN=45159006\&site=ehost-live

Petrenko, Y., Vechkinzova, E., \& Antonov, V. (2019). Transition from the industrial clusters to the smart specialization of the regions in Kazakhstan. Insights into Regional Development, 1(2), 118128. https://doi.org/10.9770/ird.2019.1.2(3)

Petridou, E., \& Ioannides, D. (2012). Conducting creativity in the periphery of Sweden: A bottom-up path towards territorial cohesion. Creative Industries Journal, 5(1-2), 119-137 http://dx.doi.org/10.1386/cij.5.1-2.119 1

Pogodina, T.V., Aleksakhina, V.G., Burenin, V.A., Polianova, T.N., \& Yunusov, L.A. (2019). Towards the innovation-focused industry development in a climate of digitalization: the case of Russia. Entrepreneurship and Sustainability Issues, 6(4), 1897-1906. http://doi.org/10.9770/jesi.2019.6.4(25)

Ray, C. (1998). Culture, Intellectual Property and Territorial Rural Development. Sociologia Ruralis, 38(1), 3- 20.

Ray, C. (2006). Neo-endogenous rural development in the EU. In P. Cloke, T. Marsden, \& P. H. Mooney (Eds.), Handbook of rural studies (pp. 278-291). London, United Kingdom: Sage.

Rimkuvienè, D., \& Sakalauskaite, M. (2018). Regional disparities in Lithuania. Management Theory and Studies for Rural Business and Infrastructure Development, 40(1), 74-84. http://doi.org/10.15544/mts.2018.07

Sacco, P. L., Blessi, G. T., \& Nuccio, M. (2009). Cultural Policies and Local Planning Strategies: What Is the Role of Culture in Local Sustainable Development?. The Journal of Arts Management, Law, and Society, 39(1), 45-64 http://doi.org/10.3200/JAML.39.1.45-6

Saleeby, D. (1996). The Strengths Perspective in social work practice: extensions and cautions. Social Work, 41(3), 296-305.

Stasiulis, N. (2017). The Idea of the Creative Society and the Development of Creative Industries. Economics and Sociology, 10(2), 217-226. doi: 10.14254/2071-789X.2017/10-2/16

UNESCO. (2015). UNESCO's Work on Culture and Sustainable Development: Evaluation of a Policy Theme. UNESCO. https://www.ces.uc.pt/projectos/somus/docs/UNESCO \%20(2015)\%20R.\%20on \%20Cult.\%20\&\%20Sust. \%20Dev..pdf

White, P. (2010). Creative industries in a rural region: Creative West: The creative sector in the Western Region of Ireland. Creative Industries Journal, 3(1), 79-88.

Yang, J., \& Černevičiūtè, J. (2017). Cultural and Creative Industries (CCI) and Sustainable Development: China's Cultural Industries Clusters. Entrepreneurship and Sustainability Issues, 5(2), 2031-242. http://doi.org/10.9770/jesi.2017.5.2(6)

Zeibote, Z., Volkova, T., \& Todorov, K. (2019). The impact of globalization on regional development and competitiveness: cases of selected regions. Insights into Regional Development, 1(1), 3347. https://doi.org/10.9770/ird.2019.1.1(3) 